\title{
The Determination of Chinese Graduate Entrepreneurship in Australia
}

\author{
Bingying Wei \\ Tasmanian School of Business and Economics, University of Tasmania, Australia
}

Copyright $(02016$ by authors, all rights reserved. Authors agree that this article remains permanently open access under the terms of the Creative Commons Attribution License 4.0 International License.

\begin{abstract}
This paper examines what factors determine Chinese graduate entrepreneurship in Australia, such as individual characteristics, entrepreneurial motivations, and environment and opportunities. The qualitative research approach was utilized to interview three Chinese entrepreneurs who started their businesses after graduation in Australia. The results indicate that personal characteristics, motivations and environmental opportunities contribute to Chinese graduate entrepreneurship in Australia. Work experience and social skills are essential individual characteristics in Chinese graduates' entrepreneurial activities. Motivations such as difficulties in finding employment and permanent residency significantly contribute to their entrepreneurship. Environments like family background and market demands give entrepreneurs opportunities to participate in entrepreneurial activities. The study recommends that individuals should develop their abilities in order to become entrepreneurs, the government should make positive policies to graduates' entrepreneurship, and the universities should encourage students by adopting more practical entrepreneurship programs.
\end{abstract}

Keywords Chinese Graduate Entrepreneurs, Australia, Entrepreneurship

\section{Introduction}

Graduate entrepreneurship is being seen as an essential source of competitive advantages of a country and the engine for economic development. In many countries, more graduates choose self-employment as a viable career path. It is not only because of intense competition for jobs in graduate labour market but also the positive government policy in encouraging graduate entrepreneurship [18]. Graduates are encouraged to become entrepreneurs and start their own businesses [48]. They have potentials in becoming entrepreneurs because the most common values among graduates are independence, self- challenge and self-realization. These attributes are necessary to entrepreneurship. In Australia, the number of Chinese graduate entrepreneurs has been growing rapidly. Graduate entrepreneurs have great impacts on the economies of both China and Australia, especially after opening up of China in 1980s and Australia's development in education industry with mushrooming number of international students [8]. It is important to examine the entrepreneurial activities of Chinese graduates in Australia.

This research aims to find out the factors that determine Chinese graduate entrepreneurship in Australia. Compared to existing literature studying graduate entrepreneurship and entrepreneurs, the number of studies focusing on Chinese graduate entrepreneurship in Australia is limited. By studying Chinese graduate entrepreneurship in Australia, major factors driving Chinese graduates into entrepreneurship will be identified. It can help gain a deep understanding of how Chinese graduates would engage in entrepreneurship in Australia.

This paper is structured as follows. Firstly, a literature review discusses existing theories and research about graduate entrepreneurship and entrepreneurs, and determinants of graduate entrepreneurship including individual characteristics, entrepreneurial motivations, and environment and opportunities. Secondly, research methods describe research design, sampling method, interviewing and transcribing, and methods of analysis. Thirdly in the analyses and findings, three interviews are analysed, which include introduction of each interviewee and business involved, and several factors influencing their entrepreneurship. Lastly, discussion and conclusions are provided.

\section{Literature Review}

This section reviews the theories and existing research in relation to Chinese graduate entrepreneurship and its determinants, including individual characteristics, entrepreneurial motivations, and environment and opportunities. 


\subsection{Graduate Entrepreneurship and Entrepreneurs}

In existing research, entrepreneurship and entrepreneurs are defined differently. On the one hand, the emphasis of entrepreneurship in some literature is on the innovation of something new with regard to the organization, processes, products and services, production methods, markets or other important aspects of a business. Hence an entrepreneur is a person of very high aptitude who desires change $[6,12,17,22,39]$. This definition derived from the study by Schumpeter [25], who firstly defines that an entrepreneur is someone who is willing and able to convert a new idea or invention into a successful innovation. On the other hand, anyone who wants to work for himself or herself is considered to be an entrepreneur in other literature. According to this definition, an entrepreneur does not have to invent something new to become an entrepreneur [32]. In this paper, entrepreneurs simply refer to the persons who want to work for himself or herself but not for someone else. Therefore, entrepreneurship equates self-employment. About graduate entrepreneurship, Nabi and Linan [17] and Gelderen and Jansen [31] point out that graduate entrepreneurship is graduate students starting business within three years after their graduation or while they are still students.

The viewpoint frequently identified by researchers is that to become an entrepreneur, the knowledge, skills, and abilities are necessary and an entrepreneur should have more positive attitudes towards independence and risk [4, 31, 43]. Trish [4] and Easton [14] state that individual characteristics such as human capital, social capital and social skills, self-efficacy, and creativity are essential in entrepreneurial activities. Therefore, the stronger abilities graduates have in these areas, the more likely that graduates can succeed in entrepreneurial activities as entrepreneurs. For graduates to become entrepreneurs, recent literature emphasize the abilities that graduates should have to become entrepreneurs, such as the ability to think logically when solving complicated and open-ended problems, and skills to establish a new venture $[4,11,20]$.

\subsection{Determinants of Graduate Entrepreneurship}

Many researches explore entrepreneurial motivations, characteristics of entrepreneurs and environmental opportunities, which are used to explain the determination of individuals' entrepreneurship.

\subsubsection{Individual Characteristics}

Literature on individual characteristics of graduate entrepreneurs focus on categorization of different personal factors that directly impact graduates to start business, such as educational background, major, gender, personality, entrepreneurial team, entrepreneurial grogram, individual capability [49], social skills [4], self-efficacy [2]. Graduates with different human capital have different abilities of entrepreneurial opportunities recognition, decision-making and operational management. The level of individual ability is the determining factor of graduate entrepreneurship $[18,23]$. Among individual characteristics of entrepreneurship, social skill has spawned a number of studies and has been considered as one of the most important entrepreneurial competencies [4, 16, 49]. In the studies, social skills refer to relationships people set up with others and develop in order to generate close connections and networks so that entrepreneurs are able to connect them to more business opportunities and access to more resources in order to start a new business successfully. In addition, several literature by several authors emphasize on the special social skills of Chinese entrepreneurs which is particularly called Guanxi in Chinese [16]. Guanxi influences the success of Chinese entrepreneurs' participation in entrepreneurial activities and determines an entrepreneur's social capital. Smith and Beasley [28] describe that Guanxi is accumulated and created through social relationships, which is one of the determinants of entrepreneurial behaviours.

\subsubsection{Motivations}

Existing literature discusses motivations of entrepreneurship, particularly focusing on necessity- and opportunity- driven motivations [10, 20, 34, 47, 49]. Necessity-motivated entrepreneurs are pushed to be entrepreneurs [22, 31]. The reasons can be employment option out of necessity [20,21,49] or income insecurity [37], which means entrepreneurs do not have other choices but taking entrepreneurial actions. According to Verheul et al. [20], opportunity-driven motivations are motives that entrepreneurs are positively looking for, such as self-challenge and achievement. Opportunity-motivated entrepreneurs are pulled into it $[11,36]$. Additionally, in some other literature, entrepreneurial motivation is classified into several elements, such as achievement/challenge/learni ng [3], independence/autonomy [37, 49], income security/financial success [39], or dissatisfaction [35]. Recent literature on motivations of graduate entrepreneurship study that graduates had increasing difficulties in finding employment. Moreover, Smith and Beasley [28] stress that the employment issue is one of the motivations why more graduates start up own business and be self-employed.

\subsubsection{Environment Factors and Opportunities}

The environment as another determinant of entrepreneurship has been studied by several authors $[12,28$, 43]. Environmental opportunities include government policies [29], culture, economics, infrastructure, family environment [28], markets and other aspects. In the studies of influences of government environment on entrepreneurship, it is identified that the positive government policy and regulation provided advantages to graduate entrepreneurs [4, 35]. Shane [45] and Vogel [15] describe the changes of environment factors, such as the changes in politics, market demands, and supplies. These are 
thought to be sources of opportunities for entrepreneurship. Entrepreneurs seek entrepreneurial opportunities by identifying, responding to, and exploiting these changes [5]. Several authors emphasize that entrepreneurship is about the ability and willingness of the entrepreneurs to perceive and create new opportunity [9, 44, 46]. In Brown's [9] study, some entrepreneurial opportunities are originated from the changes in market demands, which indicate that a new opportunity occurs when the demand increases. Moreover, opportunity identification has been studied by several authors. Different scholars have different focuses about determinants of opportunity identification, such as entrepreneurial alertness, prior knowledge from work or customer, education [1, 7, 27, 30, 40]. Qing [27], and Hansen, Shrader and Monillor [13] state that entrepreneurs will evaluate finance, investment return and other factors to determine if the opportunity is worth investing before making it into a real business. Additionally, several studied suggest that entrepreneurs with specialized knowledge and experience in markets are more active in looking for opportunities and are more likely to recognize an opportunity successfully $[1,19,24,42,45]$.

Based on the above review, it can be concluded that individual characteristics, entrepreneurial motivations and environmental opportunities have influence on individuals' entrepreneurship. Personal factors influence graduate entrepreneurs in recognising entrepreneurial opportunities, making decisions to start business and managing business. The motivations about graduate entrepreneurship can be categorized as necessity-related and opportunity-related. About recognising entrepreneurial opportunities, the changes of environment give entrepreneurs chances to discover and respond to new opportunities.

\section{Methods}

\subsection{Case Study Method}

The primary objective of the paper is to investigate the determinations of Chinese graduate entrepreneurship in Australia. The study employed interviewing as the primary qualitative research method. General face-to-face interviews with three Chinese interviewees in Australia were conducted. There are three requirements for choosing interviewees for this investigation. The interviewees must be Chinese people, graduates from Australian universities, and entrepreneurs who have businesses in Australia. Interview questions focused on how environment factors, individual characteristics, and entrepreneurial motivations determined interviewees' entrepreneurship and other follow-up questions. Each interview took about two hours. Unlike quantitative research, qualitative research allows the interviewer to ask follow up questions and try to understand the meaning of what interviewees say during the conversation [41]. Interviewing is an easier way for interviewees because they can feel free to share their experience. Three interviews were decided to take after reviewing a paper about sampling in interviews of qualitative research [41]. Ayob, Yap, Sapuan and Rashid [33] point out that the interviewees should be representative and willing to talk about the entrepreneurial experience. To sample three appropriate candidates, several Chinese entrepreneurs in Australia were referred by several Chinese communities. Three respondents, Interviewee A (owner of a cafe), B (owner of Asian restaurants) and C (owner of a hotel) were chosen from three different industries.

\subsection{Interviewing and Transcribing}

The interview questions were sent to interviewees several days before interviews by emails. The interviews took place in interviewees' café, restaurant and hotel. All conversations were in Chinese because Chinese was the first language for both interviewer and interviewees. The conversations were around two hours' long each and tape recorded in Chinese. Positive communication skills were required when having a conversation with people who were not very familiar with. The interviewer must talk actively and arrange the questions in a proper management to increase the efficiency of the conversation [33]. After interviews, all audio recordings were prepared to be transcribed for analysis. Because all interviews were in Chinese, the first step of transcribing was to directly transcribe all interview recordings in Chinese words. Then all Chinese materials were translated into English.

\subsection{Method of Analysis}

In data analysis, thematic analysis was used to analyse interview recordings and the written texts are broken down into units before analysis [26, 38]. First, key themes related to determinants of the entrepreneurial activities were coded, including individual characteristics, entrepreneurial motivations and environmental opportunities. These three key themes were the primary themes. Second, secondary themes that specifically describing each participant's personal characteristics, motivations and opportunities during their entrepreneurial behaviours were coded. Themes with similar meaning were captured and grouped to conclude the main idea of interviewees' statements. These themes were coded as the secondary themes. For example, the secondary theme "permanent residency" was coded from "Honestly I opened my own café in order to apply permanent residency because self-employer was eligible to apply permanent residency", which one category of entrepreneurial motivations. According to the content analysis of three interview materials, six, five and three categories were formulated under individual characteristics, motivations and environmental opportunities respectively. Then, secondary themes from three respondents were compared in Table 1 below to determine how common these factors have influence on their entrepreneurship. 


\section{Analyses and Findings}

The analyses describe the findings of determinants of three Chinese interviewees' entrepreneurial behaviours in Australia. The following paragraphs are structured as below, a brief description of each interviewee's business, factors that influence each interviewee's entrepreneurship, and a summary of determinants of their entrepreneurship. According to the findings, the factors that influence interviewees' entrepreneurship were categorized in Table 1.

Table 1. Factors that influence three interviewees' entrepreneurship

\begin{tabular}{|c|c|c|c|c|}
\hline Primary Themes & Secondary Themes & A & B & $\mathrm{C}$ \\
\hline \multirow{2}{*}{$\begin{array}{c}\text { Individual } \\
\text { Characteristics }\end{array}$} & Work Experience & Yes & Yes & Yes \\
\hline & Personal Capabilities & Yes & Yes & Yes \\
\hline \multirow{4}{*}{ Motivations } & Interests & Yes & Yes & Yes \\
\hline & Permanent Residency & Yes & Yes & Yes \\
\hline & $\begin{array}{c}\text { Difficulties in } \\
\text { Finding Employment }\end{array}$ & Yes & Yes & No \\
\hline & $\begin{array}{l}\text { Freedom and } \\
\text { Independence }\end{array}$ & Yes & No & No \\
\hline \multirow{2}{*}{$\begin{array}{l}\text { Environment and } \\
\text { Opportunities }\end{array}$} & Family and Friends & Yes & Yes & Yes \\
\hline & Market Demands & Yes & Yes & No \\
\hline
\end{tabular}

\subsection{Interviewee A: Owner of Café}

The first interviewee $\mathrm{A}$ is the owner of a café. He graduated from University of Tasmania in 2007 and opened a café in Hobart CBD since 2010. He earned Bachelor's degree of accounting and settled down in Australia after graduation.

\subsubsection{Individual Characteristics}

\section{Work Experience}

A's work experience as a barista in a café taught him how to work in a café efficiently and confidently, which contributed to his entrepreneurship. A was able to look through all orders quickly and improve the speed of coffee making during busy time.

'With more practice and experience, when I quickly look through all orders, I can sort these orders in my mind and know which orders can be put together. After that, I can save approximately 3 to 5 seconds for each coffee and that will be a large amount of time when the number of orders is huge. Also, the experience makes me more confident because I know how to deal with any situations when running a cafe, like angry customers or busy lunch time.'

\section{Personal Capabilities}

A was interested in running a café because of his personal capabilities, which are the professional knowledge and skills learned during barista tutorials and accounting knowledge learned from university. First, he admitted that his professional skills about coffee and coffee making from his part-time job as a barista for one year and several barista tutorials were really helpful. Second, A said the accounting knowledge he learned during university study was useful when deciding which business to take. It took him nearly one year to decide the location of café and which business to take. There were several websites advertising businesses for sale and he was able to see if the business could make profit, whether the actual profit was reliable, and how much potential the business could develop in the future.

I learned a lot about coffee making in my barista tutorials. For example, one kilogram of coffee beans can make 70-100 cups of coffees. It depends on what sort of basket I will handle. There are 6 to 9 grams of single basket, 12 to 22 grams of double baskets. Most commonly used baskets are 7 grams and 14 grams. The deeper basket I use, the more coffee beans I will consume and surely the better the coffee is.

'It is easier to see the financial report of a chain business because it is usually more detailed. But some small and individual businesses don't have any financial report but only everything in head. That would be more risky. I will see information in the financial report or $P \& L$ (profit \& loss), including annual sales, cost of sales, net profit, gross profit. Then I can have the basic information of that business. Other costs include rent, milk bill, coffee bean bill, soft drink bill, employees' roster and hourly wage. Basically I can know if I will make profit or not.'

\subsubsection{Motivations}

\section{Interests}

A said his interest of coffee culture was one of his entrepreneurial motivations. He believed that it was difficult to run a café successfully without his interest of coffee culture. As a Chinese entrepreneur owning a café, A was able to communicate with customers effectively, understand how to run his business smoothly, and most importantly, love the culture of coffee.

I am really interested in coffee culture and coffee making, especially the latte art. That is definitely one of the motivations for me to open a cafe. I mean, I wanted to become an entrepreneur because I had interest in what I wanted to do. Interest is everything I did for my cafe.'

\section{Permanent Residency}

Another motivation of A's entrepreneurial behaviour was Australian permanent residency. He had to concern about his residency after graduation and having own business was one of the ways to apply permanent residency in Australia.

'Honestly I opened my own café in order to apply permanent residency because self-employer was eligible to apply permanent residency. Rather than holding a temporary visa, I had more rights and 
advantages living and having business in Australia.'

Difficulties in Finding Employment

Difficulties in finding employment is another motivation of A's entrepreneurship. In the last semester of his bachelor's degree, A was somehow confused about the career path after graduation, self-employment or work for others. It was tough for international students, especially recent graduates, to get jobs immediately after graduation.

'Employment issue is always a big problem among all international students in Australia. I was thinking that I didn't have any professional work experience related to my major at university and my English level was not proficient enough. I was not confident about finding a job in an established company in Tasmania. After graduation, I barely knew my friends having great jobs in Australia. So I was planning to start my own business immediately after I finished university.'

Freedom and Independence

One of A's motivations to start own business rather than being employed in established company was because he wanted more freedom and independence at work. A thought working for others would sacrifice his freedom because he had to follow the workplace rules as required.

'I wanted to have my own business since college because I don't want to work like it's the daily routine of my life, being at office at 9am and finish work at 5pm, working overtime if required by supervisor etc. After I had my own café, I was able to decide my work time because I could ask my employees to manage the café if I was not there. Also, I don't have to report to anyone else because I am the owner. I have more independence working for myself.'

\subsubsection{Environment and Opportunities}

Family and Friends

A's social networks was one of determinants of his entrepreneurship. Some of A's friends started their businesses in Australia. They motivated A to open his own cafe because he had advices and information from them of doing business in Australia.

'My friends kept telling me about the advantages of having own business and their stories and experience about starting business after graduation. They also were willing to help me with my business. They kind of motivated me to plan my own career path after university.'

\section{Market Demands}

The market demands of cafés gave A an opportunity to start his business. However, A found that there were not many cafés in Hobart. He believed opening a café must be profitable because of the huge market demands. A wanted to open a café with distinguishing features in order to attract coffee lovers to come to his place.

I found that people were always looking for popular and special café in the town, but there were quite few popular cafés here. I was thinking about opening a café with distinguishing features and popular food, probably with some Asian features.'

\subsubsection{Summary}

The interview with A suggests that eight factors were critical to the decision of A to involve in entrepreneurship. These include work experience, personal capabilities, interests of coffee culture, permanent residency, difficulties in finding employment, freedom and independence, family and friends, and market demands.

\subsection{Interviewee B: Owner of Restaurants}

The second interviewee is the owner of three Asian cuisine restaurants. B has lived in Australia for more than ten years and she has already opened three restaurants with considerable profit and brand awareness. At the early stage, it was not easy to open a restaurant because B did not have any experience in running a restaurant.

\subsubsection{Individual Characteristics}

\section{Work Experience}

Her work experience as a waitress and cashier in a Chinese restaurant also contributed to B's entrepreneurship. Working in a Chinese restaurant let her know how the business really worked and made her more confident to run her own restaurant.

I I used to have part-time job in a Chinese restaurant as a waitress and cashier. I got really low pay but I did learn something about running a restaurant. I don't have real experience running a restaurant all by myself but working in the Chinese restaurant was helpful.'

\section{Personal Capabilities}

B believed that her social skill was an essential personal capability of her entrepreneurship. To have a positive relationship with her customers brought her more new customers and more positive word-of-mouth.

'Running a restaurant in Australia is sort of like in China, because we have many frequent customers. They are not only my customers but my friends. Once we have good relationship, they will come to my place more frequently and bring their friends and families. That's how I run my restaurant.'

\subsubsection{Motivations}

Interests 
Self-challenge stimulated B's interests of running a restaurant, which was another motivation determining B's entrepreneurship. She was willing to challenge herself to open a restaurant without any previous experience about restaurant running.

I think self-employment is more challenging and interesting than being employed because I must take all risks on my own even if I lost money by running my own restaurant. I was lucky to run my restaurant successfully.'

\section{Permanent Residency}

One of motivations of B's entrepreneurship was that she would be eligible to apply permanent residency by starting business after graduation. Fortunately, the permanent residency was easily to acquire at that time. As an international graduate, B became permanent resident after having her own business two years in Australia.

'One important reason was that our student visa would expire in several months after graduation and we had to think about our residency after graduation if we wanted to live in Australia. That was probably the reason why lots of Chinese people opened a restaurant.

Difficulties in Finding Employment

B applied for several full-time jobs before she made the decision to open a restaurant. The difficulties in finding employment partly motivated her entrepreneurial behaviours.

I applied some jobs before graduation but I didn't get any feedback from those companies. It was too difficult to live here independently but I had to plan my future because I wanted to settle down in Australia.'

\subsubsection{Environment Factors and Opportunities}

Family and Friends

$\mathrm{B}$ believed that her family background contributed to her entrepreneurial behaviours. Her parents were running a central air-conditioning system company in China. Both of them were typical Chinese entrepreneurs in China with strong social skills and Guanxi relations. B asked her parents for suggestions and they all insisted on her opening a restaurant. More importantly, they would like to give her some financial support.

'I think the spirit of entrepreneurship among Chinese people is in our blood, which means we believe that having own business is success in career, and Chinese people are hard-working, just like my parents. I guess my family background is also one of the reasons I started my own business here. Also, without their financial support I cannot start that easily.'

\section{Market Demands}

B said the market demands of Asian restaurants contributed to her entrepreneurship. The competitions among Asian restaurants were not as intense as they are now, because the number of Asian people and Asian restaurants was few several years ago. However, B saw the huge opportunities as the number of Asian restaurants was few but Asian food was popular among both Australian and Asian people.

\section{'At that time, there were not many Asian restaurants in Tasmania, neither were Asian people. However, as I knew Asian food was quite popular among local people, such as Japanese food, Thai food and Chinese food. When I was in the university, I used to invite local people to my place for simple Chinese food and they all loved them. So I was thinking that I could open an authentic Asian restaurant in Hobart because the demand for Asian food was largely higher than the existing supply at that time. The number of Asian restaurants was few and the taste of food there were not authentic.'}

\subsubsection{Summary}

The interview with B shows that seven factors had great influence in her decision to involve in entrepreneurship, which can include work experience, personal capabilities, interests, permanent residency, difficulties in finding employment, family and friends, and market demands.

\subsection{Interviewee C: Owner of Hotel}

The last interviewee $\mathrm{C}$ is the marketing development manager and partner of a hotel. $\mathrm{C}$ was born in a family with business background and he was taught how to do business since very young. He earned Master's Degree of International Business and started his business after graduation. He took a hotel, which was located in the centre of city. He was responsible for developing a particular market segment for the hotel and promoting products and services to current and prospective customers. The main skills and competencies for his role were to assist with developing the market for the hotel, focus on growing existing accounts and harvesting new prospects, evaluate demographics, prices and distribution channels, develop sales strategies and meet clients to achieve sales goals.

\subsubsection{Individual Characteristics}

\section{Work Experience}

Work experience was essential for C's entrepreneurship. While he was studying at university, $\mathrm{C}$ had some internship, part-time work experience and volunteer works to increase his working experience. He observed how people run business in Australia and found out the difference between running business in Australia and China.

'During university, I earned some work experience, 
like volunteering at library, taking part-time job at McDonalds, and having internship at a local company. All these experience are important for me to start my own business. They gave me opportunity to interact with different people and deal with different situations at work.'

Personal Capabilities

C's personal capabilities contributed to his entrepreneurial activities, especially his social skills. C believed that it was important to have good relationship with local people and communities in order to run business in Australia. Chinese people, especially those who want to be entrepreneurs, must have excellent social skills and are good at building long-term relationship with others. Therefore, $\mathrm{C}$ seized every opportunity to build his social networks, which facilitated him with his business in the future.

'The top issue, honestly, in starting own business is probably the difficulty to let local people and communities to treat Chinese entrepreneurs as same as local entrepreneurs. Therefore social skills are essential. Using your social skills is just like doing business in China and your social network will help you some day.'

\subsubsection{Motivations}

Interests

As a Chinese entrepreneur, $\mathrm{C}$ believed that language barrier was not the toughest problem but the strong interests of a person to start business in a foreign country. $\mathrm{C}$ faced many challenges before starting the business, such as the competitive bidding and contract with previous hotel owner. $\mathrm{C}$ did not give up and kept going on until it worked out finally. His strong interests as an entrepreneur led to his success in business.

'I am a committed and determined individual and do everything at a high standard. Doing business is not like being employed because the owner must undertake everything, good or bad. I believe that not everyone can be a successful entrepreneur unless he/she has strong interests in becoming an entrepreneur, is willing to take risks, has determination and commitment, and likes challenges.'

\section{Permanent Residency}

Permanent residency was the only motivation of C's entrepreneurship. $\mathrm{C}$ started to apply permanent residency after running this hotel as the marketing manager. The government was still processing his application, which would take probably one and a half years.

'I did not think about permanent residency before graduation because my parents wanted me to run my family business in China after I graduated. Fortunately, I had the opportunity to run a hotel and also applied the permanent residency while running my business. I thought that also worked for me.'

\subsubsection{Environment and Opportunities}

Family and Friends

C's family and friends provided him positive opportunities when he had a chance to take the hotel. Firstly, the support from C's family motivated him to start his business. Because of financial support and family business experience from his parents, $\mathrm{C}$ was easily starting his career. Secondly, C's entrepreneurial team member, who was his friend and previous marketing manager of that hotel with years of experience in hotel management and rich social networks, was a significant determinant of C's entrepreneurial behaviours. It was also that manager told him that hotel was for sale and asked if $\mathrm{C}$ was interested in taking that hotel. They made an agreement to work together to run the hotel.

'My parents supported me a lot, I mean, both financially and emotionally. They told me how to take the hotel with their own experience. It's different in China and in Australia, but doing business follows similar principles. And sure, their financial support is essential because I don't have that much money as a fresh graduate.'

'My friend really helped me a lot. We are a great team. It is great to work with someone who has the same goal and interests with me. He shared lots of information and ideas with me, which gave me lots of chances to develop my business. That is really useful. For example, we also made agreement with several business partners, like travel agencies, to bring more customers to the hotel. That is for mutual benefits. And he advised me not to hire international students who had lived here for a short period. Even I could reduce the salary expenses but most of them cannot communicate to guests deeply and smoothly to offer best service experience and give them advices about tourist attractions in Tasmania. I hope our entrepreneurial team can be larger someday because I would love to expand my business with more talents in business.'

\subsubsection{Summary}

Five factors were concluded from the interview with $\mathrm{C}$, which were essential to the decision of $\mathrm{C}$ to become an entrepreneur. These include work experience, personal capabilities, interests of being an entrepreneur, permanent residency, and family and friends.

\section{Discussion and Conclusions}

Based on the analyses of interviews, it is clear that individual characteristics, entrepreneurial motivation and entrepreneurial environments contribute to the 
entrepreneurship of three Chinese graduates in Australia, which positively testify the conclusion made from the literature review. Firstly, individual characteristics including work experience and personal capabilities have influence on interviewees' entrepreneurship. According to Table 1, work experience and personal capabilities are the common determinants of three interviewees' entrepreneurship. Secondly, four entrepreneurial motivations determine interviewees' entrepreneurship. These factors are interests, permanent residency, difficulties in finding employment, and freedom and independence. Interestingly, three interviewees started business in order to apply permanent residency in Australia. However, it was rarely reviewed in the literature. Also, interest is another common attribute of respondents' motivations in entrepreneurship. Moreover, two of interviewees consider the difficulties in finding employment as their motivation of entrepreneurship. Thirdly, environmental factors including family and friends, and market demands gave interviewees opportunities to start business. According to Table 1, family and friends is the common environmental factor among three interviews. In addition, market demands influenced two of three interviewees' entrepreneurship.

To conclude, three determinants including individual characteristics, entrepreneurial motivations, and environment factors contribute to Chinese graduate entrepreneurship in Australia. Among different factors, work experience, personal capabilities, interests, permanent residency, and family and friends are common determinants of three interviewees' entrepreneurship. In addition, difficulties of job search and market demands are important factors determining Chinese graduate entrepreneurship in Australia. The limitation of this paper is that only Chinese graduate entrepreneurs were interviewed without comparing with graduates from other countries. By studying the determinations of entrepreneurship of graduates from other countries, such as Indian, Malaysian or Korean graduates, distinguishing characteristics of Chinese graduate entrepreneurs can be compared and discussed. For further research, it is recommended that several interviews of graduates from other countries can be taken in order to compare with Chinese graduate entrepreneurs. For example, three Malaysian graduate entrepreneurs in Australia can be interviewed under the same interview structure. The results of findings from the three interviews can be used to compare with findings of Chinese interviewees.

According to the analysis of study, several recommendations can be made. The first suggestion is to improve the ability of graduates to become entrepreneurs. Graduates need to accumulate work experience and develop their social skills in order to be entrepreneurs. The second recommendation is the cultivation of a greater entrepreneurial environment and atmosphere. Government plays a significant role in facilitating entrepreneurship. Appropriate policies could be adopted to create more opportunities and provide encouragement for graduate entrepreneurship. Meanwhile, public service awareness should be improved to increase efficiency. The government should complete the marketing economic system and offer a fair and healthy competition environment. The third recommendation is that the universities should give university students more opportunities to let them involve in entrepreneurship education practically. By participating in entrepreneurship-related program, university students are able to develop entrepreneurial awareness and be confident in the real business situations.

\section{REFERENCES}

[1] A. Ardichvili, R. Cardozo. A model of the entrepreneurial opportunity recognition process, Journal of Enterprising Culture, Vol. 8(2), 103-119, 2000.

[2] A. T. Bernstein, E. G. Carayannis. Exploring the Value Proposition of the Undergraduate Entrepreneurship Major and Elective Based on Student Self-Efficacy and Outcome Expectations, 265-279, 2011.

[3] B. A. Friedman. Predictors of Students' Desire to be an Entrepreneur: Kyrgyzstan, Georgia, and the United States, Eurasian Journal of Business and Economics, Vol. 5(9), 129-140, 2012.

[4] B. Trish. 21st Century Knowledge, Skills, and Abilities and Entrepreneurial Competencies: A Model for Undergraduate Entrepreneurship Education, Journal of Entrepreneurship Education, Vol. 15, 41-55, 2012.

[5] C. Dorin, G. S. Alexandru. Dynamics of the entrepreneurship concept literature review, 2014.

[6] C. Dunn, A. Gallon. Developing Entrepreneurship in Undergraduates: The Incubation Model, 2012.

[7] C. Hägg. Entrepreneurial Opportunities - Knowledge as an influence, 2014.

[8] C. Inglis. Australia and China-Linked by Migration, CHINA EXPRESS - ISSUE 2.

[9] C. R. Brown. Economic Theories of the Entrepreneur: A Systematic Review of the Literature, 2007.

[10] C. R. Stoner, F. L. Fry. The entrepreneurial decision: Dissatisfaction or opportunity, Journal of Small Business Management, 39-44, 1982.

[11] C. Williams, J. Round, Evaluating informal entrepreneurs' motives: evidence from Moscow, International Journal of Entrepreneurial Behaviour \& Research, Vol. 15, 94-107, 2009.

[12] D. F. Kuratko, R. M. Hodgetts. Entrepreneurship: Theory, process, practice, OH: South-Western College Publishers, 2004.

[13] D. J. Hansen, R. Shrader, J. Monillor. Defragmenting Definitions of Entrepreneurial Opportunity, Journal of Small Business Management, Vol. 49(2), 283-304, 2011.

[14] E. E. Easton. Entrepreneurship: undergraduate option, concentration, or what? Journal of Small Business Management, 41-45, 2001. 
[15] E. H. Vogel. Entrepreneurial Opportunity Recognition and Exploitation in the Academia: a Dynamic Process of Networking, 2012.

[16] F. M. Yu, Y. M. Zeng. The case study of undergraduate entrepreneurship behaviors and influence, 2010.

[17] G. Nabi, F. Linan. Graduate entrepreneurship in the developing world: intentions, education and development, Education \& Training, Vol. 53, No. 5, 325-334, 2011.

[18] G. Nabi, R. Holden. Graduate entrepreneurship: intention, education and training, Education \& Training, Vol. 50, No. 7, 545-551, 2008.

[19] I. Kirzner, Competition and Entrepreneurship, University of Chicago Press, Chicago, 1973.

[20] I. Verheul, R. Thurik, J. Hessels, P. Van der Zwan. Factors Influencing the Entrepreneurial Engagement of Opportunity and Necessity Entrepreneurs, EIM Research Reports, 2012.

[21] J. Block, M. Wagner. Necessity and Opportunity Entrepreneurs in Germany: Characteristics and Earnings Differentials, Munich Personal RePEC Archive Paper, 2006.

[22] J. Block, P. Sandner. Necessity and opportunity entrepreneurs and their duration in self-employment: evidence from German micro data, Journal of Industry, Competition and Trade, Vol. 9, No. 2, 117-337, 2009.

[23] J. McKeown, C. Millman, R. S. Srikanth, K. Smith, L. M. Martin. Graduate entrepreneurship education in the United Kingdom, Education \& Training, Vol. 48, No. 8/9, 597-613, 2006.

[24] J. S. Park. Opportunity recognition and product innovation in entrepreneurial hi-tech start-ups: a new perspective and supporting case study, Technovation, Vol. 25, 739-752, 2005.

[25] J. Schumpeter. The theory of economic development: an inquiry into profits, capital, credit, interest, and the business cycle, Transaction Publishers, 1934.

[26] K. Neuendorf. The content analysis guidebook, Sage Publications, 2002.

[27] K. Qing. A Research on the Entrepreneurial Opportunity Identification Based on the AHP-TOPSIS Method, Proceedings of the 8th International Conference on Innovation \& Management, pp. 650-655, 2011.

[28] K. Smith, M. Beasley, Graduate entrepreneurs: intentions, barriers and solutions, Education \& Training, Vol. 53, No. $8 / 9,2011$

[29] L. Chandan, A. J. Mumtaz. Strategies for developing the success of small medium enterprises in Pakistan, International Journal of Business \& Management, 23-46, 2009.

[30] M. S. Gunda. Opportunity recognition levels among IT entrepreneurs in South Africa, 2013.

[31] M. V. Gelderen, P. Jansen. Autonomy as a start - up motive, Journal of Small Business and Enterprise Development, Vol. 13, 23-32, 2006.

[32] N. Ahmad, R. G. Seymour. Defining entrepreneurial activity: Definitions supporting frameworks for data collection.

[33] N. Ayob, C. S. Yap, D. A. Sapuan, M. Z. A. Rashid. Social entrepreneurial intention among business undergraduate: an emerging economy perspective, Gadiah Mada International Journal of Business, Vol. 15, No. 3, 249-267, 2003.

[34] N. Bosma, S. Wennekers, J. E. Amorós. Entrepreneurs and Entrepreneurial Employees Across the Globe 2011 Extended Report: Entrepreneurs and Entrepreneurial Employees, 2011.

[35] N. Noorderhaven, R. Thurik, S. Wennekers, A. Stel. The Role of Dissatisfaction and per Capita Income in Explaining Self-Employment across 15 European Countries, Entrepreneurship Theory and Practice, Vol. 28(5), 447-465, 2004

[36] O. Giacomin. Opportunity and/or necessity entrepreneurship? The impact of the socio-economic characteristics of entrepreneurs, 2011.

[37] P. D. Reynolds, R. T. Curtin. Business Creation in the United States: Panel Study of Entrepreneurial Dynamics II Initial Assessment, Foundations and Trends in Entrepreneurship, Vol. 4(3), 155-307, 2008.

[38] R. P. Weber. Basic content analysis, Newbury Park, CA: Sage Publications, 1990.

[39] R. Uddin, T. Kanti. Motivation, Success Factors and Challenges of Entrepreneurs in Khulna City of Bangladesh, Vol. 5(16), 148-157, 2013.

[40] S. A. Alvarez, J. B. Barney. Discovery and creation: Alternative theories of entrepreneurial action, Strategic Entrepreneurship Journal, Vol.1 (1-2), 11-26, 2007.

[41] S. E. Baker, R. Edwards. How many qualitative interviews is enough? Expert voices and early career reflections on sampling and cases in qualitative research, 2014.

[42] S. Kaish, B. Gilad. Characteristics of opportunities search of entrepreneurs versus executives: sources, interests, general alertness, Journal of Business Venturing, Vol. 6(1), 45-61, 1991.

[43] S. Kumara. Undergraduates' Intentions Towards Entrepreneurship: Empirical Evidence From Sri Lanka, Journal of Enterprising Culture, Vol. 20, No. 1, 105-118, 2012 .

[44] S. Shane, S. Venkataraman, The Promise of entrepreneurship as a Field of Research, SME's by researchers, Industry and Higher Education, 217-221, 2000

[45] S. Shane. Prior knowledge and the discovery of entrepreneurial opportunities, Organizational Science, Vol. 11(4), 448-469, 2000

[46] S. Wennekers, A. R. Thurik. Link in entrepreneurship and economic growth, Small Business Economics, Vol. 13, No. 1, 27-55, 1999.

[47] U. Stephan, M. Hart, C. C. Drews. Understanding motivations for entrepreneurship - a review of recent research evidence, Enterprise Research Centre, 2015.

[48] Y. H. Ye. The Effect of temporal distance on Chinese undergraduates' entrepreneurial decision making, Social behavior and personality, Vol. 41, No. 7, 1125-1132, 2013.

[49] Y. Robichaud, R. LeBrasseur, K. V. Nagarajan. Necessity and Opportunity-driven Entrepreneurs in Canada: An Investigation into their Characteristics and an Appraisal of the Role of Gender, Journal of Applied Business and Economics, 2013. 